\title{
Impact of high concentrations of manganese on the survival of short neck clam Ruditapes philippinarum juveniles in sandy tidal flat sediment in Ariake Bay, Kyushu, Japan
}

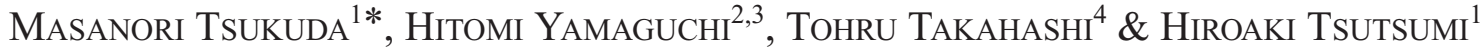 \\ ${ }^{1}$ Faculty of Environmental and Symbiotic Sciences, Prefectural University of Kumamoto, 3-1-100 Tsukide, Kumamoto 862-8502, \\ Japan \\ ${ }^{2}$ Graduate School of Fisheries Science, Hokkaido University, 3-1-1 Minato Hakodete, Hokkaido 060-0810, Japan \\ ${ }^{3}$ Present address: Center for Marine Environmental Studies (CMES), Ehime University, 2-5 Bunkyou, Matsuyama, 790-8577, \\ Japan \\ ${ }^{4}$ Faculty of Health Science, Kumamoto Health Science University, 325 Izumi, Kumamoto 861-5598, Japan
}

Received 7 January 2007; Accepted 27 October 2007

\begin{abstract}
Ruditapes philippinarum is a popular edible clam that occurs densely on the sandy tidal flats on the Japanese coast. However, on the tidal flats in Ariake Bay in Kumamoto Prefecture, western Japan, the clam suffered from extremely high mortality just after settlement on the sediment and this mortality seriously affected the population persistence of the clam. In this study, we focused on the negative impact of manganese in the sediment on the juvenile clam. We surveyed manganese ion concentration in the interstitial water of the sediment on three different sandy tidal flats facing Ariake Bay in Kumamoto Prefecture and one in the west coast of Korea. We conducted laboratory experiments exposing juvenile clam just after settlement to different contents of manganese dioxide in the sediment or manganese ion in the water: with sand containing high content of manganese dioxide $\left(2,300 \mathrm{mg} \mathrm{kg}^{-1}\right.$ dry sediment; henceforth Experiment 1); with seawater containing $5.4 \mathrm{mg} \mathrm{L}^{-1}$ of manganese ion (Experiment 2); and with natural sand and seawater containing $5.4 \mathrm{mg} \mathrm{L}^{-1}$ of manganese ion (Experiment 3). Significant mortality was not noted in Experiment 1 or in Experiment 2, while high mortality was seen in Experiment 3. In the field survey, we detected manganese ion concentration in the interstitial water at only $2.78 \mathrm{mg} \mathrm{L}^{-1}$ on the Arao Tidal Flat. However, we confirmed that manganese ion concentration in the interstitial water became more than $40 \mathrm{mg} \mathrm{L}^{-1}$ in the extraction test with the sediment on the Arao Tidal Flat. These results indicate that manganese ion liquated from the sediment into the interstitial water, due to reduction of manganese oxide, may influence seriously the physiology of juvenile clams on the tidal flats.
\end{abstract}

Key words: Ariake Bay, juvenile clam, manganese ion, mortality, Ruditapes philippinarum, tidal flat

\section{Introduction}

Along the coasts of Ariake Bay and Yatsushiro Sea in Kumamoto Prefecture, Kyushu, western Japan, large tidal flats over 10,000 ha in total area are distributed, including Midori River Tidal Flat (2,200 ha), Shira River Tidal Flat (1,100 ha), Kikuchi River Tidal Flat (800 ha) and Arao Tidal Flat (1,600 ha) (Fig. 1), and this accounts for approximately $20 \%$ of the total areas of the tidal flats remaining on the Japanese coast (Environmental Agency 1994). Most of these tidal flats are sandy where filter-feeding bivalves in-

*Corresponding author: Masanori Tsukuda; E-mail, g0575002@pu-kumamoto.ac.jp cluding Ruditapes philippinarum, Mactra veneriformis, Meretrix lusoria and Solen strictus occur at high densities (Kikuchi 2000). They all are edible clams, and fisheries harvesting these clams are very popular on the tidal flats.

Among these edible clams, $R$. philippinarum is one of the most dominant species in the macrobenthic communities in both density and biomass on the sandy tidal flats (Tsutsumi et al. 2000, Yamaguchi et al. 2004, Tsutsumi 2005a, 2005b, 2006). In 1977, 65, 732 tons of the harvest of the clam was recorded in Kumamoto Prefecture, which accounted for approximately $45 \%$ of the total annual harvest of the clam in Japan in those days. However, the clam harvest from the sandy tidal flats decreased drastically in the 1980s. In 1995 to 1997, an annual clam harvest of less 
than 1,800 tons was recorded (Ministry of Agriculture, Forestry and Fisheries of Japan 2005), although the large sandy tidal flats were still preserved on the coast of Ariake Bay.

The collapse of the population of R. philippinarum suggested that a serious environmental disturbance was imposed on the clam population on the sandy tidal flats in the 1980s. However, very limited ecological information on the occurrence of Ruditapes population remained on the process of the drastic decrease of the harvest on the sandy tidal flats in the 1980s. At least, it was not caused by overharvesting by the fishermen, since the clam harvest did not recover after almost all of the fishermen left from the tidal flats in the late 1980s to the early 1990s (Tsutsumi et al. 2000).

As to the possible causes of the collapse of Ruditapes population on the sandy tidal flats, Kajiyama et al. (1983) and Fujimori et al. (1983) suggested the influence of a large amount of mud sedimentation on the tidal flats following heavy rain on the survival of the clam. Nakahara \& Nasu (2002) and Ishii et al. (2001) suggested that predation by shore birds, crab, eagle ray (Aetobatus flagellum) and snail (Glossaulax didyma) caused the collapse of the clam populations on the tidal flats. Tamaki (2004) reported that the clam suffered a lethal effect for respiration through the bioturbation of the sediment caused by a ghost shrimp, $\mathrm{Ni}$ honotrypaea japonica in benthic study on Shira River Tidal Flat partly connected to Midori River Tidal Flat in this study. Ishii et al. (2001) and Ishii \& Sekiguchi (2002) emphasized the importance of survival rate in the pelagic larval stage.

On Midori River Tidal flat, the ghost shrimp does not occur at high densities in the fishing sites of the clam. Although the marked decrease in the number of recruits may influence the population persistence of the clam on the tidal flats, Tsutsumi et al. (2000) found that 3,000 to 6,000 indiv. $\mathrm{m}^{-2}$ of clam with less than several millimeter in shell length occurred on the substrate on Midori River Tidal Flat in 1996, when the clam harvesting fisheries stopped temporarily on the tidal flat, but they suffered from extremely high mortality. Such high mortality of the juvenile was also found in the clam on Arao Tidal Flat in 2000 (Tsutsumi 2005a), and in mussel, Musculista senhousia, on Midori River Tidal Flat in 1996 (Tsutsumi et al. 2000). These bivalves, therefore, could not establish their populations in consequence of undergoing the high mortality after settlement on the sediment.

On the other hand, a fishermen's cooperative association succeeded in re-establishing dense patches of the clams on the newly created sand covers on the Midori River Tidal Flat, using natural sand collected from the sea floor of the offshore areas of Ariake Bay in 1996 (Tsutsumi et al. 2000). Tsutsumi et al. (2002) estimated that the annual production of $R$. philippinarum population on the sand covers without extremely high mortality after settlement was equivalent to that on the tidal flat in the late 1970s to the early 1980s, when the clam harvesting fisheries were most popular. As the total area of the sand covers increased on Midori River Tidal Flat since 1995, the annual clam harvest in Kumamoto Prefecture gradually has recovered (Tsutsumi 2005). Thus, on Midori River Tidal Flat and Arao Tidal flat, the survival of the juvenile clam controlled the establishment of the dense patches of the clam on the tidal flats. Therefore, we suspect the negative impact of the substances contained in the sediment on the physiology of the juvenile clam as the ultimate factor that caused the collapse of the clam population on the tidal flats.

Previous studies on the negative influence of the contaminants in the sediment and water on the clams, R. philippinarum and a closely related species, $R$. decussates, occurring in European coast, reported that heavy metals, surfactant linear alkylbenzenesulfonate and other substances affected the enzyme activities and production of metallothionein of these species (Blasco \& Puppo 1999, Delvalls et al. 2002, Hamza-Chaffai et al. 2002, Shin et al. 2002). On the tidal flats of Kumamoto Prefecture, Tsutsumi et al. (2003) examined the content of various heavy metals of the surface sediment on the tidal flats, and found high extremely contents of manganese in the sediment $(1,400$ to $2,900 \mathrm{mg} \mathrm{kg}^{-1}$ dry sediment) on Midori River Tidal Flat and Arao Tidal Flat. The manganese contents in the sediment was usually much lower on the tidal flats, $300-450 \mathrm{mg} \mathrm{kg}^{-1}$ dry sediment (Sone Tidal Flat in Seto Island Sea, western Japan Banzu Tidal Flat in Tokyo Bay, central Japan, Hichirrip Lagoon in Hokkaido, northern Japan, unpublished data); $250-480 \mathrm{mg} \mathrm{kg}^{-1}$ dry sediment (Banweol Tidal Flat in Korea (Jung et al. 1996)); $80-452 \mathrm{mg} \mathrm{kg}^{-1}$ dry sediment (Cádiz Bay in Spain (Delvalls et al. 2002)). In Ariake Bay, there was a clear trend approximated by a geometric function in the relationship between the manganese content of the surface sediment and the biomass of $R$. philippinarum on the fishery grounds on these tidal flats. Dense patches of the clam with biomass of 295 to $6,740 \mathrm{gWW} \mathrm{m}^{-2}$ were established in the sediment containing 300 to $930 \mathrm{mg} \mathrm{kg}^{-1}$ dry sediment of manganese content of the sediment, while only less than $14 \mathrm{gWW} \mathrm{m}^{-2}$ of the clam occurred in the sediment 1,400 to $2,900 \mathrm{mg}$ $\mathrm{kg}^{-1}$ dry sediment of manganese on Midori River Tidal Flat and Arao Tidal Flat, which suffered from extremely high mortality of juveniles after settlement (Tsutsumi et al. 2003).

Manganese is an essential heavy metal involved in many metabolic functions of both plants and animals (Johnson \& Nielsen 1990, Fraust da Silva \& Williams 2001). However, when found in excess it becomes toxic and impairs many physiological functions (Barden \& Niel 1998). For example, the Norway lobster, Nephrops norvegicus, was influenced by manganese ion, which was liquated out at least $1.7 \mathrm{mg} \mathrm{L}^{-1}$ from the sediment with anaerobic conditions in the Baltic Sea (Barden et al. 1995). Manganese ion accumulated in gill, gonad, musculature exoskeleton, and influenced the function of the blood pigment, and caused serious 
trouble in respiration and feeding (Barden et al. 1990, 1994, 1995, 1999, Eriksson 2000a, 2000b). Soft clam, Macoma balthica, suffered from the physiological disturbance, due to accumulation of manganese in the water containing $1.1-20 \mathrm{mg} \mathrm{L}^{-1}$ of manganese ion (Karpevich \& Shurin 1977, Kaitala 1988).

On the tidal flats, manganese tends to deposit in the sediment as manganese dioxide, but it is easily liquated as manganese ion into the interstitial water of the sediment by bacterial reduction (Hunt \& Kelly 1988). Therefore, it is likely that manganese deposited in extremely high concentration over $1,000 \mathrm{mg} \mathrm{kg}^{-1}$ dry sediment in the sediment imposes a physiologically critical effect on the survival of juvenile clams on Midori River Tidal Flat and Arao Tidal.

In this study, we focus on the negative impact of manganese in the surface sediment and manganese ion in the interstitial water of the surface sediment on the survival of juvenile clam just after settlement. We surveyed manganese ion concentration in the interstitial water of the sediment at the same sampling stations on the three major sandy tidal flats in Kumamoto Prefecture that face Ariake Bay (Arao
Tidal Flat, Kikuchi River Tidal Flat and Midori River Tidal Flat) and a sandy tidal flat in Inchon, Korea (Seonjedo Tidal Flat), with those of Tsutsumi et al. (2003), and conducted laboratory experiments on the physiological tolerance of young juveniles with shells of less than $1 \mathrm{~mm}$ in length to different concentrations of manganese ion in the water and manganese dioxide in the sediment. We report the results of the field surveys and the laboratory experiments, and discuss the negative impact of manganese contained in the sediment on the survival of juvenile clam as one of the main causes of the collapse of the clam population on the sandy tidal flats in the 1980s.

\section{Materials and Methods}

\section{Study area}

Fig. 1 shows the study areas of this study. In the eastern coast of Ariake Bay in Kumamoto Prefecture, we established five sampling stations on each of the three sandy tidal flats, Arao Tidal Flat (Stn A1-A5; $32^{\circ} 58^{\prime} 55^{\prime \prime} \mathrm{N}$,

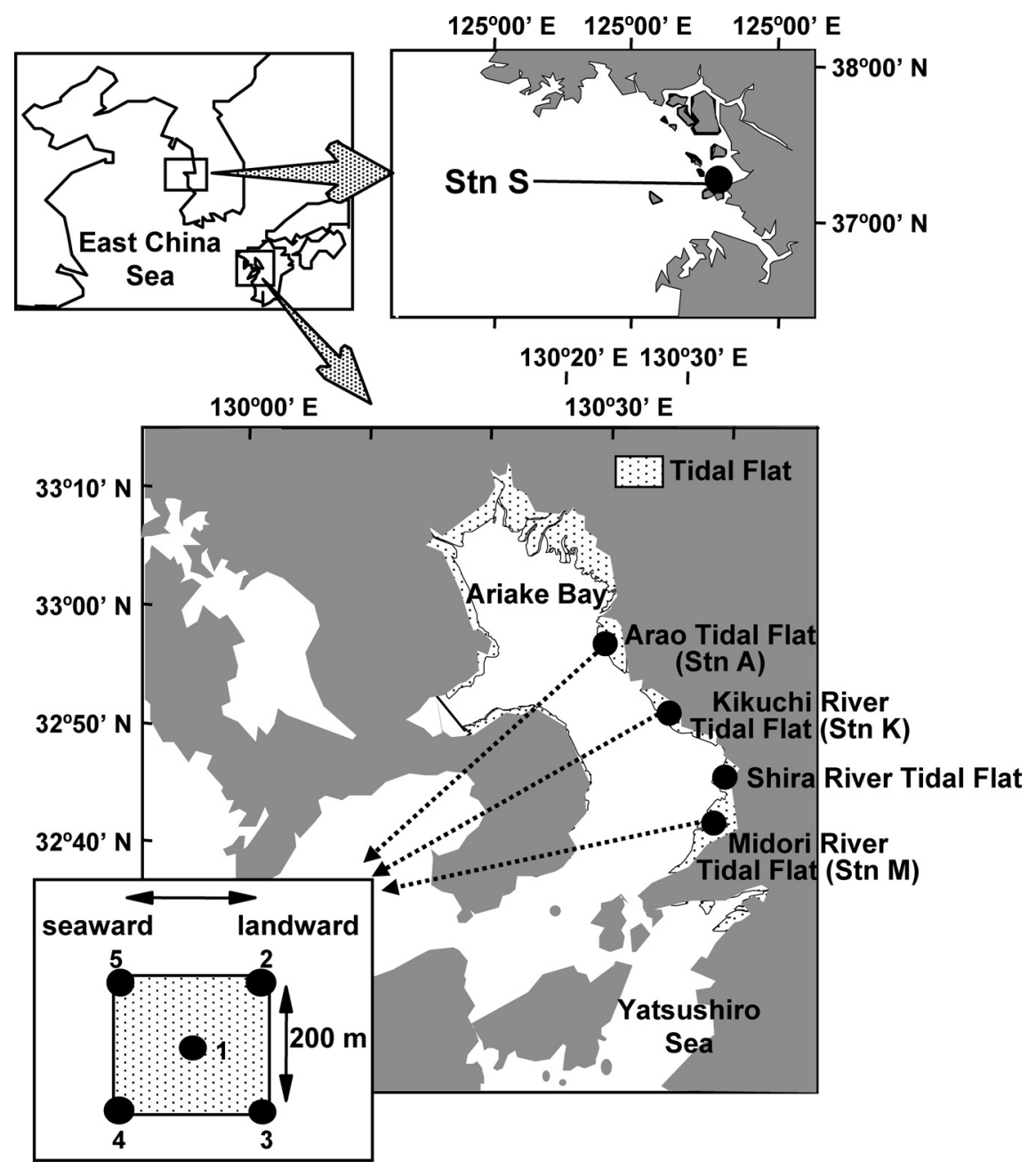

Fig. 1. Sampling stations on three tidal flats on the coast of Ariake Bay in Kumamoto Prefecture, Kyushu, Japan and on a tidal flat, Seonjedo, in the suburban areas of Inchon, Korea. 
$130^{\circ} 25^{\prime} 40^{\prime \prime} \mathrm{E}$ ), Kikuchi River Tidal Flat (Stn K1-K5; $32^{\circ} 51^{\prime} 45^{\prime \prime} \mathrm{N}, 130^{\circ} 30^{\prime} 31^{\prime \prime} \mathrm{E}$ ) and Midori River Tidal Flat (Stn M1-M5; 32 $43^{\prime} 54^{\prime \prime} \mathrm{N}, 130^{\circ} 51^{\prime} 45^{\prime \prime} \mathrm{E}$ ), which were set at the four corner and the center of an area of 200 meter square. The areas of these three sandy tidal flats are 1,656 ha, 1,007 ha, 2,100 ha, respectively (Environmental agency 1994). The tidal ranges on these tidal flats reach approximately 5 $\mathrm{m}$ in spring tide. We also established a sampling station on the sandy tidal flat of Seonjedo (Stn S; $37^{\circ} 14^{\prime} 34^{\prime \prime} \mathrm{N}$, $\left.126^{\circ} 32^{\prime} 21^{\prime \prime} \mathrm{E}\right)$ in the suburban area of Inchon, Korea. The tidal range of this tidal flat reaches approximately $9 \mathrm{~m}$ in spring tide, approximately 65,000 ha of a mega tidal flat appear at low tide (Hong 2000). Both of these sandy tidal flats in Japan and Korea are common fishery sites of harvesting clam.

\section{Field surveys for determination of manganese ion con- centration in the sediment}

We surveyed manganese ion concentration in the interstitial water of the sediment on the three sandy tidal flats in Kumamoto Prefecture, Arao Tidal Flat (Stn A1-A5), Kikuchi River Tidal Flat (K1-K5) and Midori River Tidal Flat (M1-M5), on June 12 to 14, 2002, and on the sandy tidal flat in Seonjedo, Korea, on October 23, 2002. At each sampling station on these tidal flats, we collected approximately $5 \mathrm{~mL}$ of an interstitial water, from the surface sediment up to $2 \mathrm{~cm}$ in depth, with a syringe attached a spine with $0.7 \mathrm{~mm}$ in diameter, following the sampling guide of the pore water (Aoki 1996).

We filtered the interstitial water samples with a disposable syringe filter (25HP020AN, Advantec Toyo Kaisha, Ltd), and kept the filtered interstitial water in glass tubes. We added a drop of nitric acid (CAS 7697-37-2, Nitric Acid (60-62\%), Wako Pure Chemical Industries, Ltd) to each glass tube to preserve the filtered interstitial water in low $\mathrm{pH}(2-3)$ conditions until analysis. We determined the manganese ion concentrations of the interstitial water, using flame atomic absorption spectrometry (Z-5310, Hitachi, Ltd).

\section{Laboratory experiments on the physiological tolerance of juvenile clam to manganese}

We collected juveniles of clam, $R$. philippinarum, just after the settlement (the shell length was $0.3-1.0 \mathrm{~mm}$ ) for the experiments from the fishery site of Kikuchi River Tidal Flat from May to December 2003. We collected the sand for the experiments from the fishery site of Kikuchi River Tidal Flat at May 17, 2003. Prior to the experiments, the sediment was dried with a freeze-dry machine and sieved with a $250 \mu \mathrm{m}$ opening mesh. We determined the manganese content of the sediment using flame atomic absorption spectrometry. It contained $300 \mathrm{mg} \mathrm{kg}^{-1}$ dry sediment of total manganese (it was mostly manganese dioxide). The seawater used for the experiments was collected from the offshore area of Ariake Bay, and filtered with GF/F filter
(Wattman International, Ltd) prior to the experiments. The salinity of the seawater was 29-30 psu. We used powder form of manganese dioxide (CAS 1313-13-9, Wako Pure Chemical Industries, Ltd) and manganese dichloride (CAS 7773-01-5, Sigma-Aldrich, Inc) as a test reagent.

\section{Experiment 1: Tolerance of juvenile clam to manganese particles contained in the sediment.}

We added powdered manganese dioxide to the sediment to set the manganese contents of the sediment used for the experiment to $300,550,800,1,300$ and $2,300 \mathrm{mg} \mathrm{kg}^{-1}$ dry sediment. We prepared twenty petri dishes $(8.5 \mathrm{~cm}$ in diameter, $7 \mathrm{~cm}$ in height), put $10 \mathrm{~g}$ of the sediment with four different contents of manganese $(300,550,800$ and $1,300 \mathrm{mg}$ $\mathrm{kg}^{-1}$ dry sediment) to five petri dishes each. These petri dishes were filled with $200 \mathrm{~mL}$ of the filtered seawater, and 10 individuals of the juvenile clam were released in each of them. These petri dishes were filled with $200 \mathrm{~mL}$ of the filtered seawater, and 10 individuals of the juvenile clam were released in each of them. The duration of this experiment was a week from November 30, 2003. These dishes were kept in an incubator at $28^{\circ} \mathrm{C}$, setting the light and dark period evenly in a day. We exchanged the seawater of the petri dishes daily. The $\mathrm{pH}$ level of the seawater in the petri dishes was maintained at around 8.1. At the end of the experiment, we counted the number of alive and dead individuals in each petri dish under a stereoscopic microscope.

We repeated Experiment 1, with minor modification, preparing twenty-five petri dishes for a week from December 22, 2003. In this experiments, the sediment of each five petri dishes contained five different contents of manganese $\left(300,550,800,1,300\right.$ and $2,300 \mathrm{mg} \mathrm{kg}^{-1}$ dry sediment).

\section{Experiment 2: Tolerance of juvenile clam to manganese ion in the seawater.}

We prepared the seawater containing four different concentrations of manganese ion $\left(0,1.4,2.7\right.$ and $\left.5.4 \mathrm{mg} \mathrm{L}^{-1}\right)$, adding manganese dichloride into the seawater. These manganese ion concentrations in the seawater were set, being based on those of the interstitial water in the sediment noted in the preliminary field surveys on tidal flats in Ariake Bay. We prepared twenty petri dishes $(8.5 \mathrm{~cm}$ in diameter, $7 \mathrm{~cm}$ in height), filled $200 \mathrm{~mL}$ of the seawater with four different concentrations of manganese to five petri dishes each, and released 10 individuals of the juvenile clam into these petri dishes. We conducted Experiment 2 using five replicates with each of four different manganese ion concentrations of the water for a week from May 18, 2003. The petri dishes were kept in an incubator at $28^{\circ} \mathrm{C}$, setting light and dark periods evenly in a day. We exchanged the seawater daily with manganese ion in the petri dishes. The $\mathrm{pH}$ level of the seawater of each petri dish was in the range 7.6-8.1. At the end of the experiment, we counted the number of alive and dead individuals in each petri dish under a stereoscopic microscope. This experiment was repeated in 
the same way from June 26, 2003.

\section{Experiment 3: Tolerance of juvenile clam to manganese ion in the seawater with sand.}

We prepared the sand without any addition of manganese particles in the same manner as Experiment 1 (the sediment contained $300 \mathrm{mg} \mathrm{kg}^{-1}$ dry sediment of the manganese dioxide particle naturally) and the seawater containing four different concentrations of manganese ion $(0,1.4,2.7$ and $5.4 \mathrm{mg} \mathrm{L}^{-1}$ ) in the same manner as Experiment 2. We put $10 \mathrm{~g}$ of the sediment and filled $200 \mathrm{~mL}$ of the seawater with four different concentrations of manganese ion to five petri dishes $(8.5 \mathrm{~cm}$ in diameter, $7 \mathrm{~cm}$ in height) of each concentration, and released 10 individuals of the juvenile clam into each petri dish. We conducted Experiment 3 using five replicates with each of four different manganese ion concentrations for a week from May 18, 2003. These petri dishes were kept in an incubator in the same manners as Experiment 2. The $\mathrm{pH}$ level of the seawater of each petri dish was in the range 7.6-8.1. At the end of the experiment, we counted the number of alive and dead individuals in each petri dish under a stereoscopic microscope. This experiment was repeated in the same way from June 4, 2003.

\section{Results}

Manganese ion concentration in interstitial water in the surface sediment on the tidal flats

Fig. 2 shows the manganese ion concentrations of the interstitial water of the surface sediment up to $2 \mathrm{~cm}$ in depth on the four sandy tidal flats. The highest concentrations of manganese ion ( 2.10 and $\left.2.78 \mathrm{mg} \mathrm{L}^{-1}\right)$ were recorded at two sampling stations on Arao Tidal Flat. On Midori River Tidal Flat, relatively high concentrations of manganese ion (1.56 and $1.40 \mathrm{mg} \mathrm{L}^{-1}$ ) were also noted at the two sampling stations. The manganese ion concentration in the interstitial water in the sediment on Kikuchi River Tidal Flat ranged between $0.02 \mathrm{mg} \mathrm{L}^{-1}$ and $0.72 \mathrm{mg} \mathrm{L}^{-1}$, and was not detectable from Seonjedo Tidal Flat.

Fig. 3 showed the relationship between the manganese

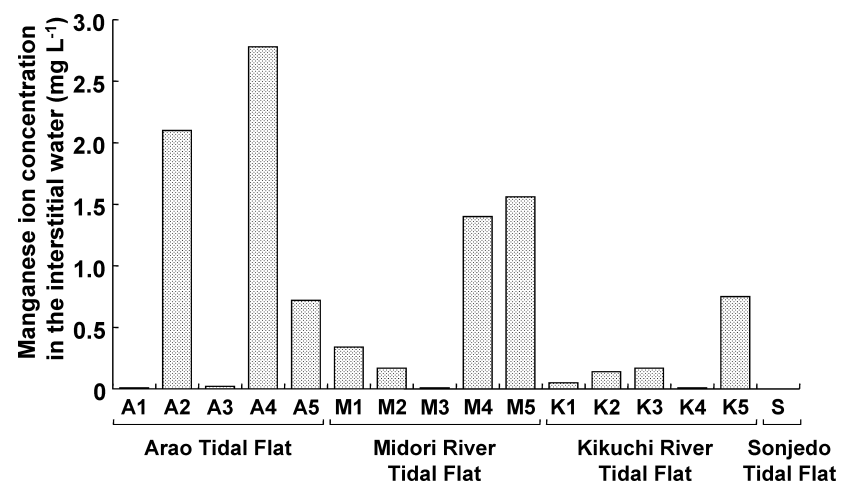

Fig. 2. The concentration of manganese ion in the interstitial water of the surface sediment on the four sandy tidal flats. content of the sediment which was referred from Tsutsumi et al. (2003) and the manganese ion concentration in the interstitial water collected at the same sampling stations on the tidal flats. Although a statistically significant relationship was not found between the manganese content of the sediment and the manganese ion concentration in the interstitial water, a weak positive correlation between them $\left(\mathrm{r}^{2}=0.21, p=0.07\right)$ indicates that at least high manganese ion concentrations in the interstitial water over $2 \mathrm{mg} \mathrm{L}^{-1}$ were not detected from the sediment containing manganese of less than $1,800 \mathrm{mg} \mathrm{kg}^{-1}$ dry sediment.

\section{Laboratory experiments on the physiological tolerance of juvenile clam to manganese}

\section{Experiment 1: Tolerance of juveniles clam to manganese particles contained in the sediment}

Fig. 4 shows the mean survival rates of the juvenile clam in Experiment 1 a week after the start. They were in a narrow range between $88.6 \%$ and $94.0 \%$ in the experiment with three different contents of manganese particles in the sediment $\left(300,550,800,1,300\right.$ and $2,300 \mathrm{mg} \mathrm{kg}^{-1}$ dry sediment). Only in the experiment using the sediment contain-

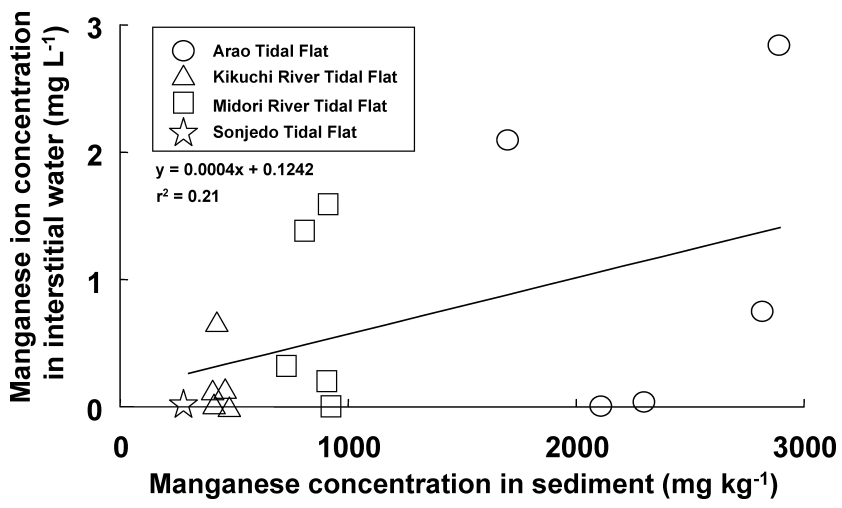

Fig. 3. The relationship between manganese concentration in the sediment and manganese ion in the interstitial water on the four different sandy tidal flats. (Data on manganese concentration in the sediment are after Tsutsumi et al. (2003))

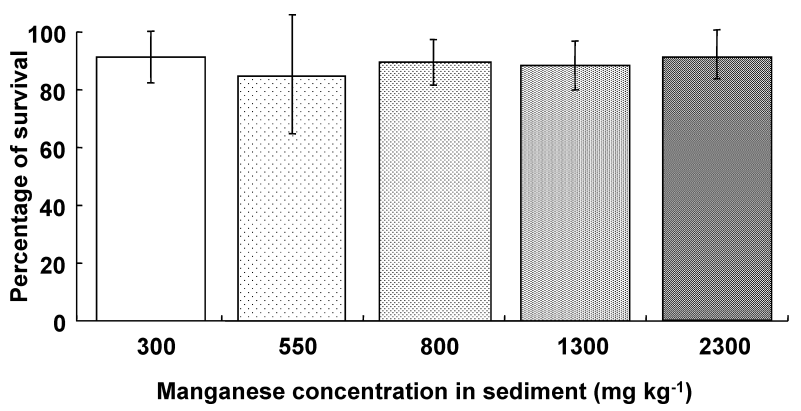

Fig. 4. Experiment 1: The mean survival rate of juvenile clam in the petri dishes with seawater and sand containing five different contents of manganese dioxide $(n=10: 300,550,800$ and $1,300 \mathrm{mg} \mathrm{kg}^{-1}$ dry sediment, $\mathrm{n}=5: 2,300 \mathrm{mg} \mathrm{kg}^{-1}$ dry sediment). 


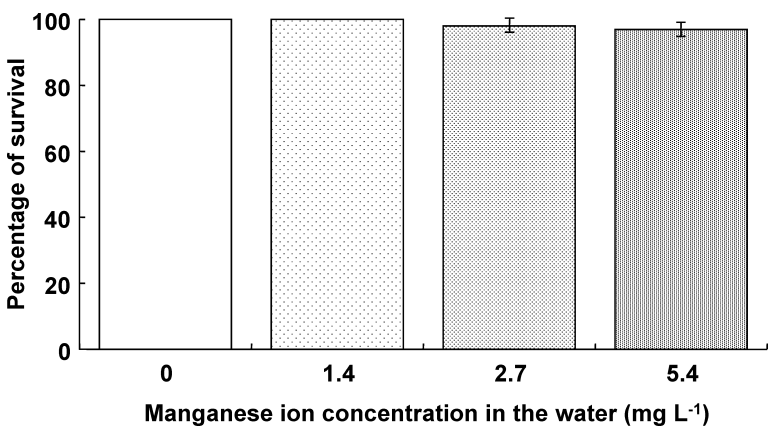

Fig. 5. Experiment 2: The mean survival rate of juvenile clam in the petri dishes with seawater containing four different concentrations of manganese ion.

ing $550 \mathrm{mg} \mathrm{kg}^{-1}$ dry sediment of manganese particles, the mean survival rate decreased to $84.4 \%$. However, the differences in the mean survival rates between the sediment with $550 \mathrm{mg} \mathrm{kg}^{-1}$ dry sediment of manganese and those containing other three different manganese contents were statistically not significant (one-way ANOVA, Turkey-Kramer multiple comparison tests, $p>0.05$ ), due to large variation of the survival rate in the experiment with the sediment containing $550 \mathrm{mg} \mathrm{kg}^{-1}$ dry sediment of manganese. Therefore, no negative influence on the survival of the juvenile clam was observed even by the exposure to the high contents of manganese in the sediment $\left(2,300 \mathrm{mg} \mathrm{kg}^{-1}\right.$ dry sediment) for a week.

\section{Experiment 2: Tolerance of juvenile clam to manganese ion in the seawater}

Fig. 5 shows the mean survival rates of the juvenile clam in Experiment 2 a week after the start. They were 97.0\% and $100 \%$ in all four different manganese ion concentrations of the seawater. Therefore the exposure of juvenile clam to manganese ion by $5.4 \mathrm{mg} \mathrm{L}^{-1}$ in the water for a week did not significantly influence the survival of the juvenile clam (one-way ANOVA, Turkey-Kramer multiple comparison tests, $p>0.05$ ).

\section{Experiment 3: Tolerance of juvenile clam in the seawa- ter containing manganese ion with sand}

Fig. 6 indicates the mean survival rates of the juvenile clam in Experiment 3 a week after the start. In the experiments with the seawater containing $0,1.4$, and $2.7 \mathrm{mg} \mathrm{L}^{-1}$ of manganese ion, they were kept in the range between $94.1 \%$ and $96.8 \%$. No negative effect on the survival of the juvenile clams was found in these three different concentrations. However, in the experiment with the seawater containing $5.4 \mathrm{mg} \mathrm{L}^{-1}$ of manganese ion, the mean survival rate of the juvenile clam decreased to $71.3 \%$. It was significantly lower than those of the three experiments with the seawater containing less than $2.7 \mathrm{mg} \mathrm{L}^{-1}$ of manganese ion (one-way ANOVA, Turkey-Kramer multiple comparison tests, $p<0.05$ ). Thus, we found the significant decrease of

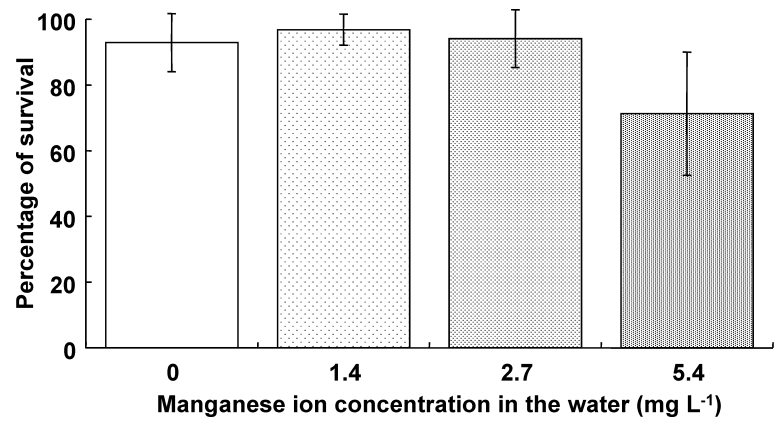

Fig. 6. Experiment 3: The mean survival rate of juvenile clam in the petri dishes with seawater containing four different concentrations of manganese ion and sand.

survival rate of juvenile clam only in the petri dishes with seawater containing $5.4 \mathrm{mg} \mathrm{L}^{-1}$ of manganese ion and the sand collected from the tidal flat.

\section{Discussion}

The most noteworthy points of this study are that the decrease of survival rate of juvenile clam did not occur in the experiments with the sand containing high content of manganese dioxide by $2,300 \mathrm{mg} \mathrm{kg}^{-1}$ dry sediment in Experiment 1 (Fig. 4) or the sea water containing manganese ion by $5.4 \mathrm{mg} \mathrm{L}^{-1}$ alone in Experiment 2 (Fig. 5), while the significant decrease of survival rate (approximately $20 \%$ decrease relative to the control experiment) occurred in the experiment with the combination of natural sand and sea water containing $5.4 \mathrm{mg} \mathrm{L}^{-1}$ of manganese ion in Experiment 3 (Fig. 6). Therefore, it is likely that the negative impact of manganese ion on the physiology of the juvenile clam is enforced by the reaction with the natural sand.

Manganese is an essential heavy metal involved in many metabolic functions of both plants and animals (Johnson \& Nielsen 1990, Fraust da Silva \& Williams 2001). However, when found in excess it becomes toxic and impairs many physiological functions (Barden \& Niel 1998). For example, the Norway lobster, Nephrops norvegicus, was influenced by manganese ion, which was liquated out at least $1.7 \mathrm{mg} \mathrm{L}^{-1}$ from the sediment with anaerobic conditions in the Baltic Sea (Barden et al. 1995). Manganese ion accumulated in gill, gonad, musculature exoskeleton, and influenced the function of the blood pigment, and caused serious trouble in respiration and feeding (Barden et al. 1990, 1994, 1995, 1999, Eriksson 2000a, 2000b). The negative influence of the manganese ion on the physiology is also reported from the bivalves. Macoma balthica suffered from the physiological disturbance, due to accumulation of manganese in the water containing $1.1-20 \mathrm{mg} \mathrm{L}^{-1}$ of manganese ion (Kaitala 1988). These facts suggest that juvenile clams of Ruditapes philippinarum undergo a negative physiological impact from manganese ion.

In the study, we demonstrated that a significant decrease in survival rate of juvenile clam occurred in the experiment 
with sand and seawater containing $5.4 \mathrm{mg} \mathrm{L}^{-1}$ of manganese ion in Experiment 3 (Fig. 6), while we detected a maximum of $2.78 \mathrm{mg} \mathrm{L}^{-1}$ of manganese ion from the interstitial water of the sediment on the tidal flats (Fig. 2). However, We might underestimate the manganese ion concentration of the interstitial water due to the technical difficulty of collecting the interstitial water from the sediment with a syringe. It is likely that the actual manganese ion concentration of the interstitial water is fairly higher than our measurements in this study. Tsutsumi (in press) already detected $9.9 \mathrm{mg} \mathrm{L}^{-1}$ of manganese ion concentration of the interstitial water on Midori River Tidal Flat.

The anaerobic decomposition process of the organic matter is partly coupled with reduction of manganese dioxide to manganese ion (Hunt \& Kelly 1988, Canfield et al. 1993). Consequently, a larger amount of manganese tends to be liquated as manganese ion into the interstitial water from the sediment with higher concentration of manganese and organic matter contents in more reduced conditions. The manganese ion liquated into the interstitial water, however, tends to be restored as the exchangeable form in the sediment again, weakly bounding electronically organic or inorganic matter. It can be released as manganese ion into the interstitial water by the action of cations such as $\mathrm{K}^{+}$, $\mathrm{Ca}^{2+}, \mathrm{Mg}^{2+}$, or $\left(\mathrm{NH}_{4}\right)^{+}$displacing manganese in relatively low pH conditions (cf. Ure \& Davidson 2002). Therefore, the amount of manganese ion that can be contained potentially in the interstitial water consists of those of manganese ion in the interstitial water and exchangeable form of manganese in the sediment.

In our follow-up study, we are trying to determine the amount of exchangeable form of manganese in the sediment that is liquated from the sediment into the magnesium dichloride solution at $\mathrm{pH} 7.0$ conditions (cf. Tessier et al. 1979). We detected approximately 11 to $44 \mu \mathrm{g}$ of exchangeable manganese liquated from $1 \mathrm{~g}$ of the dry sediment collected on Arao Tidal Flat. Since the water content of the sediment was approximately $30 \%$ (approximately $0.3 \mathrm{~mL}$ of sea water was contained per $1 \mathrm{~g}$ of the wet sediment), the manganese ion concentration in the interstitial water potentially was estimated to approximately 40 to $150 \mathrm{mg} \mathrm{L}^{-1}$. Therefore, it is likely that the manganese ion liquated from the sediment into the interstitial water imposes a serious negative impact on the physiology of the benthic animals such as bivalves, in particular juveniles just after settlement, in the sediment, since they seem to be physiologically weak.

Although the presence of manganese itself influences the physiology of aquatic animals (Beirão \& Nasciento 1989, Barden et al. 1990, Barden et al. 1994, Barden et al. 1995, Barden \& Niel 1998, Barden et al. 1999, Eriksson 2000a, b), it has active catalytic reactions with organic and inorganic matters (Maruo 2005). Hwang et al. (2001) reported that cytotoxic organic matter was produced from the chemical reaction with manganese ion and 1-hydroxypyrene under exposure to sunlight. The results of Experiment 3 in this study suggest that manganese ion contained in the water catalytically accelerate chemical reactions with natural sand or organic/inorganic matter adhered on the sand, and seriously disturb the physiological activities of the juvenile clams.

Now, we are monitoring the environmental conditions of the sediment and the interstitial water on the tidal flats, modifying the sampling techniques and the analysis methods to determine the manganese ion concentration in the interstitial water, and repeating the tolerance experiments of juvenile clams, analyzing the chemical reactions catalyzed by manganese ion in the water. From these studies, we would like to clarify the cause of high mortality of juvenile clam in the sediment containing extremely high content of manganese on the tidal flats.

\section{Acknowledgments}

We gratefully acknowledge the students of the Laboratory of Marine Ecology, Faculty of Environmental and Symbiotic Science, Prefectural University of Kumamoto, the staff of the department of agriculture, forestry and fisheries of Tamana City Office, Kawaguchi Fishery Cooperative Society, Arao Fishery Cooperative, Nameishi Fishery Cooperative Society and Ohhama Fishery Cooperative Society for assistance in the fieldwork on the tidal flats of Ariake Bay. We also thank Dr. J. S. Hong, for assistance to the sampling on the tidal flats in Inchon, Korea, and Dr R. Shinohara and Dr. M. Koga for helpful comments on the laboratory experiments and chemical analysis of the sediment. We would like to express our thanks to Mr. Richard Lavin for his critical reading for the manuscript.

\section{References}

Aoki T (1996) Pore water sampling techniques. (Kangekisui no Sampuringu hou). In: Samugawa K and Hiiro K (eds) The latest sediment analysis and chemical dynamic (Saishin no teishitsubunseki to kagakudoutai), Gihoudo, Tokyo, pp. 37-38. (in Japanese)

Baden SP, Depledge MH, Hagerman L (1994) Glycogen depletion and altered copper and manganese handling in Nephrops norvegicus following starvation and exposure to hypoxia. Mar Ecol Prog Ser 103: 65-72.

Baden SP, Eriksson SP, Gerhardt L (1999) Accumulation and elimination kinetics of manganese from different tissues of the Norway lobster Nephrops norvegicus (L.). Aqua Toxicol 46: 127-137.

Baden SP, Eriksson SP, Weeks MJ (1995) Uptake, accumulation and regulation of manganese during experimental hypoxia and normoxia by the decapod Nephrops norvegicus (L.). Mar Pollut Bull 31: 93-102.

Baden SP, Niel DM (1998) Accumulation of manganese in the haemolymph, nerve and muscle tissue of Nephrops norvegicus (L.) and its effect on neuromuscular performance. Comp Biochem Physiol A 119: 351-360.

Baden SP, Phil L, Rosenberg R (1990) Effects oxygen depletion on 
the ecology, blood physiology and fishery of the Norway lobster Nephrops norvegicus (L.). Mar Ecol Prog Ser 67: 141-155.

Beirão PS, Nasciento JHM (1989) Sodium- and Calcium-dependent mechanisms in the action potential of the secretory epithelium of a Clam Mantle. J Exp Mar Biol Ecol 145: 395-402.

Blasco J, Puppo J (1999) Effect of heavy metals $(\mathrm{Cu}, \mathrm{Cd}$ and $\mathrm{Pb}$ ) on aspartate and alanime aminotransferase in Ruditapes philippinarum (Mollusca: Bivalvia). Comp Biochem Physiol C 122: 253-263.

Canfield DE, Jorgensen BB, Fossing H, Glud R, Gundersen J, Ramsing NB, Thamdrup B, Hansen JW, Nilesen LP, Hall POJ (1993) Pathway of organic carbon oxidation in three continental margin sediments. Mar Geol 113: 27-40.

DelValls TA, Forja JM, Gómez-Parra A (2002) Seasonality of accumulation, toxicity, and quality values in sediments from littoral ecosystem in the Gulf of Cádiz. Chemosphere 46: 1033-1043.

Environmental Agency (1988) Monitoring method of sediment (Teishitsu Chousahouhou to Sono Kaisetsu), Japanese Environmental Measurement \& Chemical Analysis Association, Tokyo, pp. 175. (in Japanese)

Environmental Agency, Japan (1994) The 4th basic surveys for the conservation of the natural environment. Report on the coastal fauna and environment (surveys on the tidal flat, algal bed and coral reef). Vol 1, Tidal Flat, pp. 291. (in Japanese)

Eriksson SP (2000a) Variation in the eggs of the Norway lobster, Nephrops norvegicus (L.). Aqua Toxicol 48: 291-295.

Eriksson SP (2000b) Temporal variation in the haemolymph and tissues of the Norway lobster, Nephrops norvegicus (L.). Aquat Toxicol 48: 297-307.

Eriksson SP, Baden SP (1998) Manganese in the haemolymph and tissues of the Norway lobster, Nephrops norvegicus (L.), along the Swedish west-coast, 1993-1995. Hydrobiol 376: 255-264.

Fraust da Silva JJR, Williams RJP (2001) The biological chemistry of the elements: The inorganic chemistry of Life. Oxford University Press, Oxford, pp. 400-416.

Fujimori T, Tsutsumi Y, Iwamura S (1983) An investigation on the mortality of short neck clam at Hataguchi section on the tidal flats (Hataguchi chisaki asari heishi chousa) No. 2 A project report of Kumamoto Prefecture Nori Institute in 1982, pp. 201-205. (in Japanese)

Hamza-Chaffai A, Pellerin J, Amiard JC (2003) Health assessment of a marine bivalve Ruditapes decussatus from the Gulf of Gabés (Tunisia). Environ Int 28: 609-617.

Hong J-S (2000) Benthos on the tidal flats in Korea (Kankoku no higata no teiseiseibutsu). In: Sato M (ed) Life in Ariake Sea (Ariakekai no ikimono tachi), Kaiyuusha, Tokyo, pp. 285-303. (in Japanese)

Hunt CD, Kelly JR (1988) Manganese cycling in coastal regions: response to eutrophication. Est Coast Shelf Sci 26: 527-558.

Hwang H-M, Shi X, Ero I, Jayasinghe A, Dong S, Yu H (2001) Microbial ecotoxicity and mutagenicity of 1-hydroxypyrene and its photoproducts. Chemosphere 45: 445-451.

Ishi R, Sekiguchi H (2002) Larval recruitment of the clam Ruditapes philippinarum in Ariake Sound, southern Japan. Jpn J Benthol 57: 151-157. (in Japanese)

Ishi R, Sekiguchi H, Nakahara Y, Jinnai Y (2001) Larval recruitment for the manila clam Ruditapes philippinarum in Ariake
Sound, southern Japan. Fish Sci 67: 579-591.

Ito $H$ (2002) What kind of animal is the clam Ruditapes philippinarum?-Introduction to its ecology and fishery. Jpn J Benthol 57: 134-138. (in Japanese)

Johnson PE, Nielsen FH (1990) Copper, manganese, cobalt and magnesium. In: Metal and Health, Advance in Metal Research. Elsevier Applied Science, Barking, UK, pp 275-299.

Jung H-S, Lee C-B, Cho Y-G, Kang J-K (1996) A mechanism for the enrichment of $\mathrm{Cu}$ and depletion of $\mathrm{Mn}$ in anoxic marine sediments, Banweol intertidal flat, Korea. Mar Pollut Bull 32: 782-787.

Kajiyama M, Fujimori T, Nojiri S (1983) An investigation of the mortality of short neck clam at Hataguchi Section on the tidal flats (Hataguchi tisaki asari heishi chosa) No. 1 project report, Kumamoto Prefectural Nori Institute in 1982, pp. 197-200. (in Japanese)

Kakiino J, Toba M, Kaneko A, Fukayama Y (1992) Mortality of Japanese little neck clam in winter season on Kisarazu Tidal Flat, Tokyo Bay. Bull Chiba Prefect Fish Exp 50: 21-30. (in Japanese)

Kakino J (2000) Habitat condition and large scale propagation on Japanese little neck clam Ruditapes philippinarum. Aquabiol 127: 143-154. (in Japanese)

Kikuchi T (2000) Meeting of conservation of ecosystem on the tidal flat and shallow water (Higata senkaiteino hozen no igi). In: Sato M (ed) Life in Ariake Sea (Ariakekai no ikimono tachi), Kaiyuusha, Tokyo, pp. 306-317. (in Japanese)

Karpevich AF, Shurin AT (1977) Manganese in the metabolic processes of mollusks of the Balthic Sea. Sov J Mar Biol 6: 437-443.

Kaitala S (1988) Multiple toxicity and accumulation of heavy metals in two bivalve mollusk species. Water Sci Technol 20: 23-32.

Kyushu Regional Agricultural Administration Office (1974-1998) Annual report of statistics on agricultural, forestry and fisheries in FY 1973-1997 (1973-1997 nendo Kumamoto-ken nourin suisan toukei nenpou) Kyushu Regional Agricultural Administration Office. (in Japanese).

Luoma SN (1983) Bioavailability of trace metals to aquatic organisms - a review. Sci Total Environ 28: 1-22.

Li X, Shen Z, Wai OWH, Li Y-S (2000) Chemical partitioning of heavy metal contaminations in sediments of the Pearl River Estuary. Chem Speciat Bioavailab 12: 17-25.

Maruo M (2005) 1.1.7 Manganese-The most active trace element (Mangan - mottomo akutibu na biryougenso). In: Sorin $\mathrm{K}$ Isshiki Y (eds) Chemistry of sea and lake (Umi to mizuumi no kagaku). Kyoto University Press, Kyoto, Japan, pp. 85-86. (in Japanese)

Ministry of Agriculture, Forestry and Fisheries of Japan (2005) The statistical annual report of fishing and fish farming production. http://www.tdb.maff.go.jp/toukei/a02smenu1?TokID= C001\&TokKbn $=$ C\&TokKbnName $=\% 92 \%$ B 7 $\% 8$ A $\%$ FA $\% 97 \%$ DD\%94N\%93\%9D\%8Cv\#TOP. (in Japanese)

National Institute of Advanced Industrial Science and Technology (AIST) (2005) Geochemical map of Japan (Kyushu region). http://www.aist.go.jp/RIODB/geochemmap/Kyushu/Kyushu.htm. Nakajima S (1982) Partitioning of heavy metals (Mn, Fe, As, Cd, $\mathrm{Pb}, \mathrm{Cu}, \mathrm{Zn}, \mathrm{Co}$ and $\mathrm{Ni}$ ) into selective chemical fractions in sedi- 
ment core from Lake Biwa. Jpn J Limnol 43: 67-80. (in Japanese)

Nakahara Y, Nasu H (2002) Report of the coastal areas of Ariake Sounds, Kumamoto Prefecture; the main fisheries ground for the clam Ruditapes philippinarum population in Japan. Jpn $\mathbf{J}$ Benthol 57: 139-144. (in Japanese)

Sasaki K (1999) Material circulation and production in estuary and tidal flat-35, Tidal flat and fishery resources 4, Japanese littleneck clam of Ariake Sea. Aquabiol 121: 162-166. (in Japanese)

Shin PKS, Ng AWM, Cheung RYH (2002) Burrowing responses of the short- neck clam Ruditapes philippinarum to sediment contaminants. Mar Pollut Bull 45: 133-139.

Tamaki A (2004) Dynamics of benthic communities on intertidal sand flats in the Ariake Sound estuarine system, with special reference to the recent decline in the manila clam yield. J Jpn Soc Water Environ 27: 301-306. (in Japanese)

Tessier A, Campbell PGC, Bisson M (1979) Sequential extraction procedure for the speciation of trace metals. Anal Chem 51: 844-851.

Tsutsumi H (2005a) Changes of physico-chemical conditions of the sediment on the tidal flats and their influence on the benthic communities - case studies on the sandy tidal flats in Ariake Bay. Gekkann Kaiyou 37: 107-115. (in Japanese)

Tsutsumi H (2005b) Marked decline of clam harvesting fisheries and environmental change on the tidal flats facing the Ariake Sea in Kumamoto prefecture. Ecol Civil En 8: 83-102. (in Japanese)

Tsutsumi H (2006) Critical events in the Ariake Bay ecosystem: Clam population collapse, red tides, and hypoxic bottom water. Plankton Benthos Res 1: 3-25.

Tsutsumi H (in press) Reduction of manganese oxide in the sedi- ment and its possible negative impact on the physiology of clam on two tidal flats, Midori River Tidal Flat and Arao Tidal Flat in Ariake Bay. Plankton Benthos Res 3.

Tsutsumi H, Ishizawa K, Tomishige M, Moriyama M, Sakamoto K, Montani S (2002) Population dynamics of a clam, Ruditapes philippinarum, on an artificially-created sand cover on the tidal flats at the river mouth of Midorikawa River. Jpn J Benthol 57: 177-187. (in Japanese)

Tsutsumi H, Takeguchi T, Maruyama A, Nakamura Y (2000) Seasonal fluctuations in the benthic community after the population collapse of a clam, Ruditapes philippinarum, on the Midori River Tidal Flat in Kumamoto. Jpn J Benthol 54: 1-8. (in Japanese)

Tsutsumi H, Tsukuda M, Yoshioka M, Koga M, Shinohara R, Nomura Y, Choi K-S, Cho H-S, Hong J-S (2003) Heavy metal contamination in the sediment and its effect on the occurrence of the most dominant bivalve, Ruditapes philippinarum, on the tidal flats of the Ariake Bay in Kumamoto Prefecture, on the west coast of Kyushu, Japan. Benthos Res 58: 121-130.

Ure AM, Davidson CM (2002) Chemical speciation in soil and related materials by selective chemical extraction, In: Ure AM, Davidson CM (eds) Chemical Speciation in the Environment, Blackwell Science, Paris, pp. 273.

Yamaguchi H, Tsutsumi H, Tsukuda M, Nagata S, Kimura C, Yoshioka M, Shibanuma S, Montani S (2004) Utilization of photosynthetically produced organic particles by dense patches of suspension feeding bivalves on the sand flat of Midori River estuary, Kyushu, Japan. Benthos Res 59: 67-77.

Yokoyama K (2005) Influence of sediment transport in the Chikugogawa and Shirakawa rivers on the coastal area of Ariake Bay. Ecol Civil En 8: 61-72. (in Japanese) 